
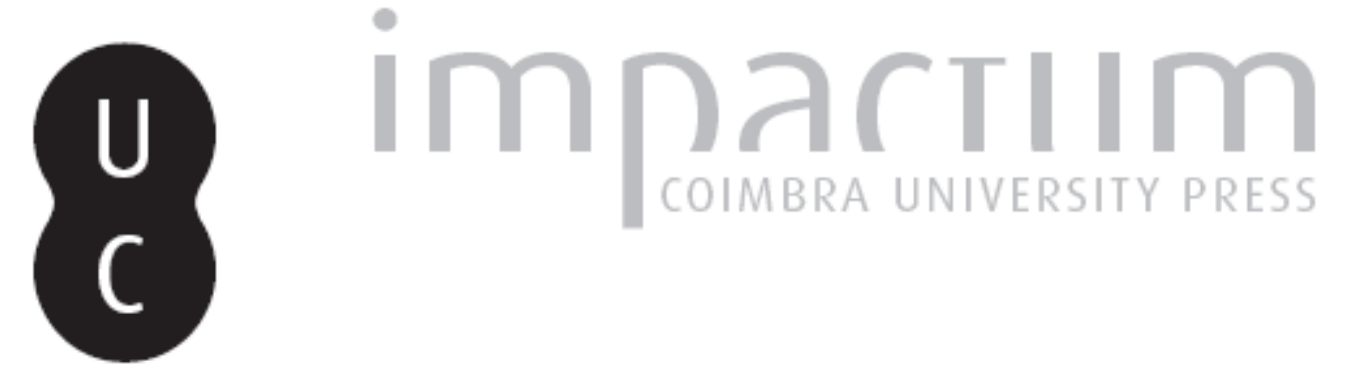

\title{
Os Direitos Humanos sob a ótica das diferentes tradições religiosas
}

Autor(es): $\quad$ Araújo, Giselle Marques de

Publicado por: Universidade Católica de Petrópolis

URL persistente:

URI:http://hdl.handle.net/10316.2/33790

DOI:

DOI:http://dx.doi.org/10.14195/2175-0947_3-1_2

Accessed : $\quad$ 26-Apr-2023 16:18:15

A navegação consulta e descarregamento dos títulos inseridos nas Bibliotecas Digitais UC Digitalis, UC Pombalina e UC Impactum, pressupõem a aceitação plena e sem reservas dos Termos e Condições de Uso destas Bibliotecas Digitais, disponíveis em https://digitalis.uc.pt/pt-pt/termos.

Conforme exposto nos referidos Termos e Condições de Uso, o descarregamento de títulos de acesso restrito requer uma licença válida de autorização devendo o utilizador aceder ao(s) documento(s) a partir de um endereço de IP da instituição detentora da supramencionada licença.

Ao utilizador é apenas permitido o descarregamento para uso pessoal, pelo que o emprego do(s) título(s) descarregado(s) para outro fim, designadamente comercial, carece de autorização do respetivo autor ou editor da obra.

Na medida em que todas as obras da UC Digitalis se encontram protegidas pelo Código do Direito de Autor e Direitos Conexos e demais legislação aplicável, toda a cópia, parcial ou total, deste documento, nos casos em que é legalmente admitida, deverá conter ou fazer-se acompanhar por este aviso.

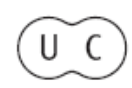



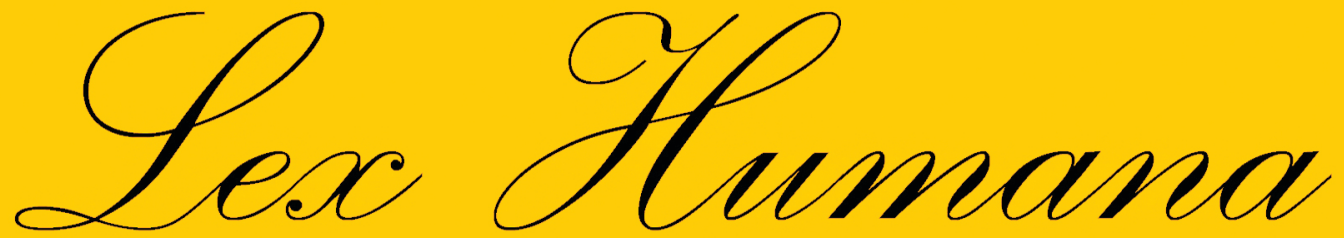

Revista do Programa de Pós-Graduação em Direito da UCP

ISSN(e) 2175-0947

Universidade Católica de Petrópolis Rua Benjamin Constant, 213 - Petrópolis - Centro CEP 25610-130

Tel: (24) 2244-4000 E-mail: lexhumana@ucp.br 


\section{OS DIREITOS HUMANOS SOB A ÓTICA DAS DIFERENTES TRADIÇÓES RELIGIOSAS ${ }^{1}$}

Giselle Marques de Araújo

Resumo: A doutrina contemporânea dos direitos humanos vem sendo construída a partir de consensos estabelecidos entre os países integrantes da Organização das Naçóes Unidas, que possibilitaram a Declaração Universal dos Direitos Humanos de 1948, aceito como mais importante documento em relação ao tema. Neste artigo, retratamos a análise de cientistas sociais que procuram verificar se existiria uma base comum entre esta doutrina e as diferentes tradiçóes religiosas por eles professadas: islamismo, budismo, confucionismo e hinduísmo. Defendemos a idéia de que as identidades tradicionais precisam ser explicitadas e valorizadas no espaço público, onde a dimensão espiritual do ser humano merece ser contemplada.

Palavras-chave: Direitos humanos; tradições religiosas; direito à diferença.

Abstract: The contemporary doctrine of human rights has been constructed from the consensus established among the member countries of the United Nations, which allowed the Universal Declaration of Human Rights 1948, accepted as the most important document in this regard. In this article we have depicted the analysis of social scientists who seek to verify whether there was common ground between this doctrine and the different religious traditions which they professed: Islam, Buddhism, Confucianism and Hinduism. We support the idea that identities need to be spelled traditional and valued in the public space, where the spiritual dimension of human being deserves to be considered.

Keywords: Human rights; religious traditions; right to difference.

\footnotetext{
${ }^{1}$ Artigo recebido em 02/05/2011 e aprovado para publicaçấo pelo Conselho Editorial em 12/07/2011.

2 Doutoranda em Direito pela Universidade Gama Filho - RJ. Currículo Lattes: http://lattes.cnpq.br/7499143357798035. E-mail: giselle marques@hotmail.com.
} 


\section{Introduçáo.}

Este artigo foi elaborado, com o objetivo de verificar como as diferentes tradiçóes religiosas vêem a doutrina contemporânea dos direitos humanos, e justifica-se na medida em que os documentos preparatórios para a Cúpula Social de Copenhague de 1995, já demonstravam uma preocupação ético-religiosa necessária para que se coloque em prática a idéia de dignidade da pessoa humana. Para tanto, utilizamos como referencial teórico um capitulo da coletânea Direitos Humanos na sociedade cosmopolita, organizada por César Augusto Baldi (2004), e que reúne interessantes artigos escritos por cientistas sociais partidários de diferentes credos e culturas.

O primeiro artigo, de autoria de Chandra Muzaffar (p.309), trata de uma possível relação entre "Islã e direitos humanos"; o segundo, escrito por Damien Keown (2004, p.323), aborda o "Budismo e direitos humanos". A seguir, vem o artigo de Tu Weiming (2004, p.359), intitulado "Os direitos humanos como um discurso moral confuciano". Estes autores procuram demonstrar que islamismo, budismo e confucionismo têm pontos em comum com a idéia de direitos humanos presente no ocidente, usando para tanto como referência a Declaraçáo Universal dos Direitos Humanos de 1948. Mas apontam também diversos indicadores que demonstram as inegáveis diferenças entre direitos humanos e estas tradiçóes religiosas.

O último artigo do referido capítulo, escrito por Ashis Nandy (2004, p.377) difere um pouco dos anteriores, pois, ao tratar da questão dos direitos humanos no induísmo, acaba por ir além, apresentando uma crítica à política do secularismo, utilizando a conjuntura do cenário atual da "religião como fé" na Índia, apenas como pano de fundo para um debate acerca da hegemonia do secularismo no mundo atual, e a tolerância religiosa dentro deste contexto.

Para o desenvolvimento deste artigo, apresentamos um resumo de cada texto retro mencionado, e, a seguir, tecemos algumas reflexóes acerca das questóes apresentadas. Para tanto, utilizamos alguns outros autores, ampliando nosso referencial bibliográfico, com o objetivo de enriquecer este diálogo, a fim de produzir uma breve contribuição acerca da discussão sobre os direitos humanos no cenário atual. 


\section{O Islã e os direitos humanos.}

$\mathrm{O}$ artigo de Chandra Muzaffar divide-se em duas partes, conforme o próprio autor nos explica: "a primeira investiga a relação entre o islá e algumas das principais idéias associadas à democracia e aos direitos humanos", enquanto a segunda argui que "o islã corporifica um conceito de ser humano que vai além dos direitos”, e que tem como pressuposto uma visão de mundo "diametralmente oposta àquela que inspira e informa o pensamento ocidental contemporâneo sobre direitos humanos" (p.309).

$\mathrm{O}$ autor argumenta que algumas das principais idéias associadas à democracia e aos direitos humanos estão em harmonia com o pensamento islâmico. Dentre estas, destaca o primado do direito, já que o Islá teria reconhecido há séculos que as decisóes, atos e procedimentos das autoridades públicas, em qualquer nível, não serão válidas, a menos que estejam de acordo com a lei, o que estaria ligado ao conceito de "devido processo legal", destacando o seguinte trecho do livro que serve como referência teórica para o islamismo, o Corão:

Sede firmes em observardes a justiça, atuando como testemunhas, por amor a Deus, ainda que o testemunho seja contra vós mesmos, contra os vossos pais ou contra os vossos parentes, seja o acusado rico ou pobre, porque a Deus incumbe protegê-los. Portanto, não sigais os vossos caprichos, para não serdes injustos; e se falseardes o vosso testemunho ou vos recusardes a prestá-lo sabei que Deus está bem inteirado de tudo quanto fazeis. (MUZAFFAR, 2004, p. 310)

Este conceito de justiça e equidade inspiraria o judiciário islâmico, garantindo a isenção, independência e neutralidade dos juízes, e estaria em consonância com a limitação do poder dos governantes, proclamada na Declaração Universal Islâmica, elaborada pelo Conselho Islâmico da Europa em 1980, que estabelece a subordinação do governante às leis, aos valores e aos princípios da religião. Esta limitação implicaria na aprovação do povo até mesmo para a utilização do dinheiro público, que deve ser obtida pelos líderes.

O autor identifica a relação entre o islã e os direitos econômicos, na medida em que o Corão confere aos pobres "um direito automático à riqueza da comunidade através da instituição da zakat" (p.312), imposto sobre a riqueza que deve ser pago por todo muçulmano 
de posses, e que constitui-se em um dos cinco pilares do islá, situando-se no mesmo nível da profissão de fé e do culto a Deus. A identificação do islã e os direitos sociais e civis, por sua vez, repousaria na determinação do Corão de que não deve existir qualquer coerção religiosa.

No tocante aos direitos políticos, Muzaffar argumenta que a partir do Corão, os juristas e os filósofos muçulmanos desenvolveram uma ampla gama de direitos políticos, o que pode ser verificado na Declaração Universal Islâmica dos Direitos Humanos de $1981^{3}$, ao reconhecer o seguinte:

Todos os indivíduos e todos os povos têm o direito inalienável à liberdade em todas as suas formas, física, cultural, econômica e política, e devem ter direito a lutar, de todas as maneiras, contra qualquer violação ou supressão deste direito; e qualquer indivíduo ou povo oprimido tem direito legítimo ao apoio de outros indivíduos e/ou povos a sua luta.

O Corão estabelece, ainda, que "é direito e dever de todo muçulmano protestar e lutar (dentro dos limites estabelecidos pela lei- Shariah) contra a opressão, mesmo que isso implique um desafio às mais elevadas autoridades de estado". Esta afirmativa é bastante interessante, e parece caminhar na contra-máo do comportamento que domina o ocidente hoje, o individualismo ${ }^{4}$. Enquanto no Ocidente o indivíduo parece estar cada vez mais afastado da atividade política, da vida na cidade, no espaço público, no Oriente as grandes massas populares se levantam, e marcham buscando a reconquista do espaço público e do poder político. Prova disso, são os recentes conflitos no Egito e na Líbia.

Por derradeiro, Muzaffar (p.314) relaciona o direito à vida, proclamado na Declaraçáo Universal dos Direitos Humanos de 1948, e também na Declaração Universal Islâmica dos Direitos Humanos de 1981, que, segundo o autor, vai além, ao dizer que a vida humana "é sagrada e inviolável, e não se devem medir esforços para protegê-la". A Declaração Islâmica afirma também: "assim como na vida, na morte, a santidade do corpo de uma pessoa deve ser inviolável. É obrigação dos fiéis garantir que o corpo de uma pessoa falecida seja

\footnotetext{
${ }^{3}$ Ver Declaração Universal Islâmica dos Direitos Humanos, Conselho Islâmico da Europa, setembro de 1981, p.7. ${ }^{4}$ A expressão individualismo é aqui empregada no sentido do indivíduo que constitui-se ele próprio no valor supremo, não podendo ser submetido a ninguém, sendo as suas regras pessoais, os valores que regulam seu comportamento.
} 
tratado com a devida solenidade". Neste aspecto, percebemos que a tradição islâmica preocupa-se com a "integridade” física da pessoa humana, mesmo após a sua morte

Haveria, portanto, inegável similitude entre os direitos humanos proclamados como fundamentais no âmbito das Naçóes Unidas, e aqueles destacados pelo Corão, que estabelece nossa responsabilidade, enquanto seres humanos, para conosco, nossa família, nossos parentes, a comunidade, o estado e até mesmo para com o ambiente natural. O papel do ser humano como marido, esposa, criança ou adulto, estaria entrelaçado intimamente com os direitos, as responsabilidades e os relacionamentos, no âmbito do Corão. Este vínculo entre direito e responsabilidade seria indispensável, para evitar as tragédias terríveis que têm ocorrido, como é o caso do fenômeno da AIDS, que para o autor seria "resultado do exercício dos direitos sexuais desacompanhado da responsabilidade sexual". E é exatamente neste ponto que a doutrina dos direitos humanos ocidentais começaria a se distanciar dos valores muçulmanos, já que a primeira estaria voltada apenas para os direitos, sem se preocupar com a responsabilidade necessária para o exercício destes.

O distanciamento entre a doutrina contemporânea dos direitos humanos e o islá, segundo Muzaffar (2004, p. 317), atinge o seu ápice quando se verifica que a primeira não está interessada em questóes metafísicas e espirituais sobre o propósito do homem e o sentido da vida, não se debruçando sobre uma pergunta fundamental: "quem é o ser humano"? Ao furtarse a este questionamento, a doutrina ocidental confirmaria sua falência moral e intelectual. $\mathrm{O}$ Corão, por sua vez, preocupar-se-ia em respondê-lo, a fim de compreender por que o ser humano está aqui, e de entender o que o indivíduo representa para a comunidade global. Para o Corão, o ser humano é representante de Deus (Khalifah Allah), encontra-se na terra para servir a Deus, para fazer a Sua vontade. Após essa vida, ele retorna a Deus, para ser julgado por seus feitos na terra.

A doutrina ocidental, ao contrário, elege o homem como o centro do universo. O ser humano individual é colocado como "medida de todas as coisas", e não precisa submeter-se a

\footnotetext{
${ }^{5}$ Neste momento, paramos para uma reflexão acerca do modo como o corpo de uma pessoa morta é tratado no Brasil, pois, uma das experiências mais chocantes que tivemos, foi a de nos deparar com um bebê da nossa família, que viveu apenas três dias, já sem vida no hospital: seus pezinhos foram presos um ao outro com fita crepe, e o mesmo foi feito com suas máozinhas. $\mathrm{O}$ corpinho nu foi abandonado numa maca de metal, como se fosse um "nada" e, daquela forma, foi apresentado a nossa família.
} 
uma autoridade superior, uma força transcendental para além de si próprio. Isto resulta na difusão de uma cultura hedonista, que alimenta o ego humano. A falta de limites a esse ego, que recebe liberdade irrestrita por não estar sujeito a uma autoridade moral superior, o leva a caminhos destrutivos. Nesse ponto, a fala de Muzaffar contribui para uma reflexão acerca da sociedade ocidental: a desagregação familiar, a descrença com o estado, a banalização do sexo e da informação, características cada vez mais presentes no ocidente. Leva-nos, ainda, a pensar na supervalorização que o dinheiro e o consumo vêm experimentando.

Atualmente, nas faculdades de direito nas quais atuamos como docentes, quando perguntamos qual o objetivo do estudante em buscar a universidade, a resposta mais freqüente é: "concurso", e, quando se vai um pouco além, questionando qual o motivo da preferência pelos concursos públicos, raramente ouvimos respostas que evidenciem a vocaçáo para o serviço público, como "servir o povo", "servir a nação", ou "contribuir para o aperfeiçoamento da máquina pública”. O que tem levado os estudantes de direito a buscar os concursos é um único atrativo: a estabilidade conferida por um bom salário. A remuneração está hoje no centro da preocupação do estudante de direito, e esta afirmativa representa um recorte de uma realidade mais ampla, a de que o dinheiro está no centro da imaginação dos cidadãos e cidadãs no ocidente, o que nos remete a uma interessante argumentação de Simmel (1998, p. 33):

Do mesmo modo que a maioria dos homens modernos precisa ter diante dos olhos, na maior parte da vida, o ganho de dinheiro como motivaçáo mais próxima, forma-se a idéia de que toda a felicidade e toda satisfação definitiva na vida são ligadas, intrinsecamente, à posse de uma certa forma de dinheiro.

A ânsia pelo dinheiro tem levado ao embrutecimento das relaçóes humanas, de modo que valores como a dignidade, a honestidade e a solidariedade deixam de ser prioritários. $\mathrm{O}$ que vale mesmo é a quantia que o ser humano tem no banco, seu patrimônio, suas roupas, seu carro, sua aparência. Segundo Baudrillard (1981, p.13), vivemos numa sociedade cujos valores se regem pelo consumo e pela abundância, que resultam num afã de multiplicação de objetos, de serviços, de bens materiais. Esta será, sob sua óptica, a ecologia própria da espécie humana: as leis ecológicas naturais foram substituídas pela lei do valor de troca. E alerta: 
O indivíduo serve o sistema industrial, não pela oferta das suas economias e pelo fornecimento de capitais, mas pelo consumo dos seus produtos. Por outro lado, não existe qualquer outra atividade religiosa, política ou moral, para a qual seja preparado de maneira táo completa, tão científica e tão dispendiosa.

Uma das conseqüências do consumismo colocado como paradigma, segundo Baudrillard, é o avanço das doenças mentais, dentre as quais a depressão, apontada por muitos especialistas como o "mal do século" da pós-modernidade, decorrente do vazio interior, que não pode ser preenchido por bens materiais. O ser humano, esvaziado de um propósito para sua vida, deixa de ver sentido em viver, entregando-se ao consumo desenfreado, ora de bens materiais, ora de substâncias psicoativas, ora de alimentos (aí talvez presente um dos fatores que justificam o avanço da obesidade no ocidente) ${ }^{6}$.

\section{Budismo e direitos humanos}

Damien Kewon (2004, p.323) afirma que seu artigo é uma contribuição para o processo amplo de discussão e aceitação que faz-se necessário para desenvolver uma filosofia budista dos direitos humanos, porque o budismo "não parece dispor de tal filosofia no momento, sendo um novato na causa dos direitos humanos". E, na defesa do budismo em face desta aparente omissão, sugere que a preocupação com os direitos humanos é um fenômeno pós-religioso, "mais relacionado às ideologias seculares e às políticas do poder do que à religião, não cabendo acusaçôes de negligência ao budismo nesta área”, segundo o autor, que, no entanto, termina por reconhecer que o budismo "está muito atrás de religiôes como o cristianismo e o islá no desenvolvimento de uma base para o evangelho social, no qual se possam traduzir questóes desse tipo”.

A despeito deste vácuo, Damien Kewon aduz que eventos políticos no curso deste século, trouxeram a questão dos direitos humanos para o topo da agenda: a invasão do Tibete pela China, o conflito étnico no Sri Lanka e a ditadura militar em Mianmar deram ao

\footnotetext{
${ }^{6}$ A obesidade, segundo Ferreira, atinge hoje proporções endêmicas mundialmente. No Brasil, as cifras são crescentes, e o percentual de indivíduos com excesso de peso supera em muito o daqueles com déficit de peso.
} 
budismo experiência neste tema, embora pouco tenha sido escrito a esse respeito. Há também, o surgimento do movimento "budismo socialmente engajado", que expressa preocupação com a injustiça social através de um vocabulário ocidental dos direitos humanos.

$\mathrm{O}$ artigo procura as bases conceituais e doutrinárias para os direitos humanos no budismo, propondo-se a investigar se existe vinculação entre elas. A primeira dificuldade para isso, surge da noção do que seria "direito", conceito que vem sendo desenvolvido há séculos no ocidente, e que, segundo nos lembra Kewon (2004, p. 327) deriva do latim rectus, do grego orektos, que significa "ereto ou vertical", e estende a noção de retidão do domínio físico ao moral. Em outras palavras, o vocábulo "direito" foi concebido como um padrão ou medida de conduta. Algo era direito- moralmente reto ou verdadeiro- se cumprisse o padrão de retidão, ou a condição de direito. Tanto "right" quanto "rectus" têm um ancestral mais remoto no sânscrito rju (reto ou aprumado). A forma equivalente em páli seria uju (reto, direto, honesto, aprumado).

Apesar da etimologia comum, no entanto, não há palavra em sânscrito ou páli que transmita a idéia de "direito", compreendida como uma prerrogativa subjetiva. Para o autor, isto não significa dizer que o conceito de direito não possa existir no budismo, apesar de não ter uma palavra para expressá-lo. Mas o budismo está mais ligado à idéia de dever (p.336). O Buda explica deveres recíprocos existentes entre pais e filhos; professores e alunos; marido e esposa; amigos, parentes e vizinhos; empregado e empregador. Os deveres de um, corresponderia às prerrogativas ou "direitos" do outro. Desta forma, o conceito de direitos estaria implícito no budismo clássico, segundo o autor, mesmo não havendo uma palavra ou expressão que possa exprimi-lo.

Em outras palavras, os preceitos budistas parecem muito diferentes das declaraçôes contemporâneas de direitos humanos, sendo expressos na forma de algo que se assume, e não de direitos. O autor, no entanto, sugere que essas diferenças são de forma, e não de substância (se existem direitos universais, existem também deveres universais). Haveria, portanto, legitimidade em falar-se de direitos, e de direitos humanos, no budismo, já que as doutrinas modernas de direitos humanos estariam em harmonia com os valores morais do budismo clássico. 


\section{Direitos Humanos como discurso moral confuciano}

Tu Weiming (2004, p.359) afirma que o discurso acerca dos direitos humanos é um discurso moral poderoso, senáo o mais persuasivo na arena internacional, podendo ser $\mathrm{o}$ instrumento mais eficaz, talvez o único, por meio do qual os padróes ordinários de comportamento dos estados podem ser julgados pela comunidade internacional, sem infringir as prerrogativas da soberania.

Abraçando a didática classificação proposta por Bobbio (1992), destaca a evolução deste discurso moral em três geraçóes: a primeira, referente aos direitos políticos; a segunda, aos direitos econômicos, sociais e culturais; e a terceira, aos direitos de grupos. Esta agenda traria implícita a idéia de uma boa sociedade, e a ética da responsabilidade de todos os governos de trabalhar para um bem comum. Haveria aí um caráter ecumênico, que estaria de acordo com os pressupostos subjacentes aos valores morais confucianos: a percepção da pessoa como centro dos relacionamentos, ao invés de simplesmente como indivíduo isolado, a idéia de sociedade como uma comunidade baseada na confiança, e a crença de que os seres humanos têm o dever de respeitar sua familia, sua sociedade e sua nação

Estes valores, segundo Tu Weiming, são compatíveis com os Direitos Humanos, e, por seu apelo universal, podem servir de inspiraçáo para representar os Direitos Humanos como linguagem comum da humanidade, como contraponto às lacunas subjacentes à filosofia politica ocidental moderna, que, segundo o autor, são as seguintes: a) tensão exclusivamente concentrada no relacionamento individuo versus estado (está excluída a familia para compreender esta relação); b)ignora as culturas do resto do mundo e os povos que não falam a língua da América do Norte e da Europa Ocidental; c)postura excessivamente litigiosa. O confucionismo surgiria, então, como uma alternativa eficaz contra estas deficiências da civilização ocidental moderna.

No texto de Tu Weiming, podemos identificar uma audaciosa sugestão, na qual sua crença religiosa seria a mais adequada para solucionar problemas do mundo atual. Ele afirma que "a discussão em profundidade dos valores asiáticos pode dar uma grande contribuição potencial para uma apreciação cultural sofisticada do discurso dos direitos humanos". Embora 
mencione que esta discussão constituirá uma oportunidade para o desenvolvimento de uma agenda verdadeiramente ecumênica, as idéias articuladas pelo autor deixam clara sua visão de que o modelo confucionista é o mais viável a ser seguido.

\section{A politica do secularismo e o resgate da tolerância religiosa.}

Ashis Nandy (2004, p.377) inicia seu artigo destacando a existência de um "certo imperialismo" das categorias existentes nas estruturas pós-coloniais modernas, em que um domínio conceitual influenciado pelo pensamento ocidental adquire a hegemonia, e o domínio original desaparece da consciência. Nesse processo, "as culturas orais passam a ser as culturas dos analfabetos, os oprimidos se transformam no proletariado e as transformaçóes sociais viram desenvolvimento". O autor propóe a apresentaçâo de um prefácio político ao resgate do domínio da tolerância étnica e religiosa, a partir da linguagem hegemônica do secularismo.

Tal prefácio parte da descrição de quatro tendências que, segundo Ashis Nandy, tornaram-se claras no sul da Ásia durante este século: a primeira e mais importante, é a de que a religiáo na Ásia passa a ser dividida em duas: fé (indicando a religiáo como estilo de vida, uma tradição não monolítica e operacionalmente plural) e ideologia (a religião como um identificador subnacional e transnacional de populaçóes contestando ou protegendo interesses não religiosos, geralmente políticos ou socioeconômicos), categorias que não seriam excludentes. Uma das diferenças entre as duas, é que a ideologia, para quem nela acredita, "é algo que precisa ser protegido", enquanto a fé, é “algo do qual os fiéis costumam esperar proteção".

A segunda tendência, segundo o autor, é a de ver as religióes mais antigas da região através do olhar do cristianismo europeu pós-medieval e suas diversas ramificaçóes, como o cristianismo masculino do século XIX, do tipo de Joshua Marshan e William Carey no sul da Ásia, ou do tipo modernista ortodoxo apregoado por Frederich Engels e Thomas Huxley. A terceira, engloba a visão de que a religião é uma ideologia oposta à do sistema de estado moderno e, assim, precisa ser contida. Este tipo de secularistas sente-se desconfortável com a "religião como fé", que nega ao estado e aos seus ideólogos de classe média o direito de "ser a reserva derradeira de sanidade e o árbitro final entre as diferentes religióes e comunidades”. 
O autor é psicólogo político e sociólogo da ciência, e, segundo nota do editor, vem trabalhando temas como culturas, etnocentrismo, conhecimentos alternativos, colonialismo e movimentos pela paz e diálogo civilizacional. Esta experiência permitiu-lhe identificar a quarta tendência, segundo a qual, a idéia importada de secularismo tornou-se cada vez mais incompatível com as "definições um pouco fluidas de self com as quais muitas culturas do sul da Ásia convivem", e que invoca e reflete os princípios configuradores das "religiōes como fé", consistindo na negação do conceito moderno de "eu" (selfhood) adquirido parcialmente do ocidente iluminista. Ashis Nandy fala aqui de self cultural, porém compatível com os estudos psicanalíticos de selfe separação, especialmente as fronteiras do ego na Índia.

O artigo apresenta uma crítica ao secularismo, ou ao sentido adquirido pelo termo, de política de separação entre religião e estado. Registra que, quando Jacob Holoyake cunhou a palavra "secularismo" em 1850, propôs um significado conciliador do termo, uma forma que pudesse acomodar a religiáo e enfatizasse as diversidades e a coexistência nas questóes da fé. E é este o sentido de secularismo que merece ser resgatado, em contraposiçáa aquele proposto por Joseph Bradlaug, que acreditava em um secularismo que rejeitasse a religiáo e tomasse a ciência como divindade.

A modernidade, enquanto princípio organizador da cultura dominante da política, ao negar espaço para os conceitos tradicionais de uma vida justa, e, ao colocar a "religiáo como fé" contra a parede, gerando uma "sensaçáo de derrota" para os crentes, levando-os à raiva e ao ódio de si mesmos, fomentaria entre os indianos o fanatismo e a violência. Quando o estado apela à comunidade minoritária para que se secularize ou confine à política secular, está a lhe dizer para "suavizar" sua fé e assim poder ser mais verdadeiramente integrada ao estado-nação. Esta "solução" não seria atraente para os fiéis, pois, para os que têm fé religiosa, a religião é uma teoria geral de vida, incluindo a vida pública, e "esta vida não parece valer a pena ser vivida sem uma teoria de transcendência, ainda que imperfeita”.

A fala de Ashis Nandy diz respeito à Índia, mas leva-nos a uma reflexão acerca do fenômeno que está acontecendo em todo o mundo, na atualidade: a exacerbada manifestaçáo de violência- seja através do terrorismo, ou de atos individuais, que nos fazem pensar acerca dos efeitos colaterais da hegemonia do pensamento secularista. Ao mesmo tempo que o estado moderno apela aos fiéis para manter a esfera pública livre da religião, abrindo mão de sua fé, 
não lhes garante proteção contra os sofrimentos causados pelo próprio estado, nem tampouco tem meios de garantir que as ideologias do secularismo, desenvolvimento e nacionalismo não comecem a funcionar como fés intolerantes com relação a outras. O assassinato de Gandhi por nacionalistas hindus, em nome de um estado secular, nesse sentido, segundo Nandy, é instrutivo, e faz-nos pensar acerca da tolerância que o estado moderno prega e requer.

As idéias de Ashis Nandy têm alcançado destaque na Índia, e polemizam com a modernidade, principalmente no que se refere à questão do desenvolvimento e do secularismo. Mas enfrentam críticas, como, por exemplo, a de legitimar o atrasado nacionalismo hindu, inclusive no que se refere a uma perspectiva ambígua que reforçaria o antifeminismo (Desai, 2002, p.78). Não haveria, por outro lado, como negar a influência da modernidade na formação de Ashis Nandy (Babber, 2006, p. 34 a 40), o que levaria à presença das dicotomias típicas das teorias da modernização em sua obra.

\section{O direito à diferença.}

A leitura dos artigos que integram a discussão acerca dos direitos humanos e as diferentes tradiçóes religiosas, na obra organizada por César Augusto Baldi, desperta a questão do que há de comum entre ambos os temas. Mas aponta também (e talvez principalmente) as diferenças entre os direitos humanos, conforme proclamados na Declaração Universal promulgada no âmbito da Organização das Nações Unidas, em 1948, e estas tradições. Com efeito, se a preocupação na segunda metade do século XX, era no sentido de construir uma pauta comum entre as diversas naçóes integrantes do mundo, buscando o consenso dentro do que poderia ser "igual”, comum ao ser humano que vive em qualquer destas naçóes, o século XXI parece apontar para uma nova necessidade: a de inexorável respeito às diferenças. É preciso, no contexto dos direitos humanos como tema global, construir mecanismos que possibilitem a expressão das especificidades e das subjetividades.

O espaço íntimo do ser humano, a esfera privada, deve ser preservada. Mas como falar em emoçóes, sentimentos, crenças, no espaço público? Como garantir o direito à fé, em um mundo cada vez menos espiritualizado? Conforme asseverou Ashis Nandy (2004, p.403), filósofos como Hannah Arendt e Herbert Marcuse já apontavam que as formas mais extremas 
de violência em nossa época não vêm de paixões problemáticas ou da irracionalidade humana, e sim de "ideologias problemáticas e da racionalidade instrumental sem limites". O secularismo tem servido como instrumento legitimador de uma racionalidade que separa religiáo e política, negando no espaço público o direito à fé.

Fiss (2005, p. 48) nos convida a repensar o papel do Estado no tocante ao direito à liberdade de expressáo, e nos alerta que a omissão do Estado, ao deixar de garantir que grupos considerados minoritários tenham a oportunidade de se expressar no espaço público, pode significar um "efeito silenciador" da voz destes grupos, o que fere de morte a diversidade e a o pluralismo do debate público. Isto nos faz pensar no efeito silenciador que o secularismo vem exercendo, ao eliminar o debate teológico, ao invés de possibilitar a coexistência das diversas religiôes em reconhecimento mútuo.

A questão da base comum de valores, que seriam inerentes a cada ser humano, indiferentemente da cultura, nação ou país em que este ser humano esteja envolvido, e que parece ser um dos objetivos da doutrina dos direitos humanos, neste momento, tem se revelado como delicada, exigindo uma reflexão mais aprofundada a respeito. Especialmente se levarmos em conta que os países africanos e asiáticos não participaram da elaboração da Declaração Universal de 1948, conforme ponderou Alves (2007, p. 27), ao relatar a polêmica instalada na Conferência de Viena, realizada de 14 a 25 de junho de 1993:

A reafirmação da universalidade dos direitos humanos constituiu, por sinal, uma das conquistas mais difíceis da Declaração de Viena. Não havendo participado da elaboração e da aprovação da Declaração Universal, e em função de seus sistemas culturais, religiosos e ideológicos diferentes daqueles do Ocidente, muitos países asiáticos e africanos insurgiram-se, no processo preparatório, contra a própria idéia dos direitos humanos que inspirou o texto de 48 . Algumas delegaçóes chegaram a declarar no Plenário e nas discussōes de trabalho da Conferência, que ela correspondia a uma tentativa de imposição de valores ocidentais sobre o resto do mundo. Sua aceitaçáo de tais direitos seria, pois, sempre condicionada à adaptabilidade de cada um desses direitos aos respectivos sistemas.

Um dos grandes desafios que o século XXI nos coloca, portanto, é o de garantir o direito de cada nação, de cada cultura, de cada tradição religiosa, à diferença, sem, no entanto, perder o caráter de universalidade reclamado pelos direitos humanos. É preciso vencer o relativismo cultural e religioso, sem, no entanto, olvidá-lo. A tarefa é delicada. Corre-se o risco 
de suprimir as vozes dos grupos minoritários, sufocando-os ou ignorando-os. Mas valorizá-los pode significar colocar em risco consensos que foram construídos após experiências traumáticas, como é o caso do respeito aos direitos humanos das mulheres, que vem sendo conquistado com o sacrifício de muitas vidas. Por isso, faz-se necessário avançar na concepçáo de unidade do ser humano, mas valorizando as particularidades de cada gênero, de cada cultura, respeitando-se os antecedentes históricos, culturais, psicológicos e religiosos de cada nação. Respeitando-as e não negando-as. Este o desafio que está colocado.

\section{Consideraçóes finais}

Todos os artigos da obra de César Augusto Baldi (2004), consultados para este trabalho, permitiram a ilustração de correntes religiosas diferentes da tradição cristã ocidental, que inspirou a elaboração da Declaração Universal dos Direitos Humanos, e continua a influenciar a doutrina dos direitos humanos no mundo atual. Os autores buscavam os pontos em comum entre as crenças por eles professadas (islamismo, budismo, confucionismo e induísmo) e a concepção ocidental dos direitos humanos. Mas foi justamente ao destacar o que os diferenciam, que referidos textos nos levaram a refletir acerca da necessidade de respeito às diferenças, no âmbito da universalidade dos direitos humanos.

As críticas que se seguiram, marcaram o ponto alto dos trabalhos, despertando questionamentos acerca dos valores cultivados atualmente no Ocidente, ligados ao "ter", e não ao "ser", com enfoque nos direitos, muitas vezes em detrimento do sentido de responsabilidade decorrente dos deveres. Este seria um dos pontos que afastaria a concepçáo ocidental dos direitos humanos das diferentes tradiçóes religiosas ali retratadas, e pode ser identificado no primeiro texto utilizado como fonte para a reflexão desenvolvida neste artigo, de autoria de Chandra Muzaffar (2004, p. 309), que busca uma relação entre o "Islã e direitos humanos", destacando vários pontos comuns entre ambos. Ao apontar o que diferencia o islamismo da doutrina dos direitos humanos, no entanto, acaba por produzir uma crítica à cultura ocidental moderna, que estaria voltada para direitos enquanto prerrogativas, às quais nem sempre corresponderiam obrigaçóes ou responsabilidades. A ênfase na cultura ocidental estaria nos 
direitos, enquanto para o Islã o foco estaria na responsabilidade de cada indivíduo para com seus pares, e para com a comunidade.

Por este mesmo motivo, no caso do budismo, seria bastante difícil encontrar uma base conceitual em comum com os direitos humanos. Damien Kewon (2004, p. 323) registra que não há nem mesmo uma palavra em sânscrito ou páli que transmita a idéia de "direito", compreendida como uma prerrogativa subjetiva. Este autor reconhece que o budismo está aquém de muitas outras tradiçóes religiosas em matéria de direitos humanos, como o caso do islamismo, e que ainda será preciso desenvolver uma base filosófica para a relação entre direitos humanos e budismo.

Tu Weiming (2004, p. 359), por sua vez, entende ser possível estabelecer uma relação entre os direitos humanos e os pressupostos subjacentes aos valores morais confucianos, que poderiam representar uma linguagem comum da humanidade, como contraponto às lacunas que o autor identifica na filosofia politica ocidental: a exclusão da família na relação entre o indivíduo e o estado, a postura excessivamente litigiosa, e o egocentrismo.

Estes posicionamentos, num primeiro momento, poderiam inspirar uma relativização dos direitos humanos, eis que erigidos sob os pilares de valores e concepções que só são aceitáveis no ocidente. Mas, num olhar mais detido, despertam a necessidade de buscarse uma universalidade para os direitos humanos que contemple a diversidade cultural, efetivando o que Arendt (1973, p. 24) chamou de "direito a ter direitos". É preciso compreender que, no nascedouro da doutrina dos direitos humanos, a civilização estava perplexa diante da divulgação das atrocidades cometidas durante a segunda guerra mundial. A conjuntura à época exigia uma resposta eficaz e imediata, que se traduziu em um documento: a Declaração Universal dos Direitos Humanos de 1948, cujos postulados passaram a inspirar as constituições democráticas modernas.

Num segundo momento, a fase de declarar os direitos humanos, foi superada por uma nova tarefa, a de efetivá-los, conforme destacou Bobbio (1992, p. 24):

Deve-se recordar que o mais forte argumento adotado pelos reacionários de todos os países contra os direitos do homem, particularmente contra os direitos sócias, não é a sua falta de fundamento, mas a sua inexequibilidade. Quando se trata de enunciá-los, o acordo é obtido com relativa facilidade, independente do maior ou menor poder de convicção de seu fundamento 
absoluto; quando se trata de passar à açáo, ainda que o fundamento seja inquestionável, começam as reservas e as oposições.

O problema fundamental em relação aos direitos do homem, hoje, não é tanto o de justificá-los, mas o de protegê-los. Trata-se de um problema não filosófico, mas político.

Desde a Conferência de Viena, e conforme os textos reunidos por Baldi, é possível distinguir que, além da efetivaçáa que os direitos humanos reclamam, é necessário buscar mecanismos que garantam o respeito às diferenças étnicas, culturais e religiosas. Náo com o objetivo de relativizar os direitos humanos, como pretendem alguns. Mas, sim, no intuito de aperfeiçoá-los, valorizando-os como tema dos mais importantes na agenda internacional.

A despeito de guerras localizadas, o mundo atualmente vive tempos de paz. O fim das disputas ideológicas entre socialismo e capitalismo, da chamada "guerra fria", cede espaço para as disputas étnicas, e as diferenças de concepção e os conflitos regionais tornam-se evidentes. Alves (2007, p.4) relata a participação dos grupos minoritários nas reunióes preparatórias da Convenção de Viena, e como as mulheres orientais atuaram ativamente no sentido de questionar os valores feministas da concepçáo atual de direitos humanos, vigente no âmbito da Organização das Naçóes Unidas. Embora o posicionamento defendido por estas mulheres, pareça um retrocesso aos pressupostos inerentes à concepção dos direitos humanos vigentes no ocidente, como alertou Habbermas (1997, p. 93), é preciso ter cuidado para não bloquear o intercâmbio horizontal de posicionamentos espontâneos e, portanto, o uso das liberdades comunicativas, identificando e denunciando aquelas estruturas que fazem com que o espectador fique passível perante o coletivo:

A imagem das massas em movimento cedeu lugar à imagem dos telespectadores integrados eletronicamente. Assim, as imagens do estado total desapareceram, permanecendo entretanto intacto o potencial destrutivo de um novo tipo de massificação.

Nesse contexto, é preciso garantir a manifestação das diferentes tradições religiosas no espaço público. É preciso respeitar a visão do ser humano enquanto marcado pela espiritualidade, não sendo apenas matéria e racionalidade. Talvez esta conquista seja possível através de uma visita ao "lugar do assombro", de que falava Arendt (1993, p. 315), afastando- 
nos da questáo de 'o que' uma coisa é, e de que tipo de coisa deve ser produzida para a questáo de 'como' e através de que meios e processos ela veio a existir e pode ser reproduzida. A doutrina dos direitos humanos está diante de um novo momento, no qual é importante refletir sobre os aspectos espirituais da condição humana. 


\section{Referências Bibliograficas}

ALVES, José Augusto Lindgren. Os direitos humanos como tema global. São Paulo: Perspectiva, 2007.

ARENDT, Hannah. A condição humana, Rio de Janeiro: Forense Universitária, 1993. , "The rights of man, what are they?" Modern Review, 3, Summer, 1949; The

origins of totalitarianism (new ed., with added prefaces), New York, Harverst Book, 1973.

ASHIS, Nandy. A política do secularismo e o resgate da tolerância religiosa. In: César Augusto

Baldi (org.). Direitos Humanos na sociedade cosmopolita. Rio de Janeiro: Renovar, 2004.

BABER, Zaheer. Secularism, communalism and the intellectuals. Gurgaon: Three Essays, 2006.

BAUDRILLARD, Jean. A Sociedade de Consumo. Lisboa: Ediçóes 70, 1981.

BOBBIO, Norberto. A Era dos Direitos. Rio de Janeiro: Editora Campus, 1992.

CONSELHO ISLÂMICO DA EUROPA, Declaraçâao Universal Islâmica dos Direitos

Humanos, setembro de 1981.

DESAI, Radhika. Slouching towards Ayodhia. Nova Déli: Three Essays Press, 2002.

FERREIRA, Sandra Roberta G.. Alimentação, nutrição e saúde: avanços e conflitos da modernidade. Cienc. Cult. [online]. 2010, v. 62, n. 4, pp. 31-33. Disponível em: http://cienciaecultura.bvs.br/pdf/cic/v62n4/a11v62n4.pdf, acesso em 01 de maio de 2011. FISS, Owen M. A ironia da liberdade de expressão: estado regulação e diversidade na esfera pública. Tradução e prefácio de Gustavo Binenbojm e Caio Mário da Silva Pereira Neto. Rio de Janeiro: Renovar, 2005.

HABERMAS, Jünger. Uma conversa sobre questôes da Teoria Política. São Paulo: CEBRAP, no. 47, 1997, p 93. Tradução: Marcos Nobre e Sérgio Costa, Novos Estudos.

KEOWN, Damien. Budismo e Direitos Humanos. In: César Augusto Baldi (org.). Direitos Humanos na sociedade cosmopolita. Rio de Janeiro: Renovar, 2004.

MUZZAFAR, Chandra. Islã e os direitos humanos. In: César Augusto Baldi (org.). Direitos Humanos na sociedade cosmopolita. Rio de Janeiro: Renovar, 2004.

SIMMEL, Georg. O dinheiro na cultura moderna. In, Jessé Souza e B. Oëlze, orgs. Simmel e a Modernidade. Brasília, Editora UNB, 1998. 
WEIMING, Tu. Os direitos humanos como um discurso moral confuciano. In: César Augusto Baldi (org.). Direitos Humanos na sociedade cosmopolita. Rio de Janeiro: Renovar, 2004 . 